\title{
Investigation of the profound causes of the not brace compliance in adolescents
}

\author{
Dimitris G Papadopoulos \\ From 7th International Conference on Conservative Management of Spinal Deformities \\ Montreal, Canada. 20-22 May 2010
}

\section{Background}

The BBS Questionnaire it has performed in different countries and seems to be reliable. The aim is to understand the profound causes of the not compliance with a scoliosis brace.

\section{Materials and methods}

We have administrated in 291 adolescents with Idiopathic Adolescents Scoliosis, the BBS questionnaire, adding one more question. The added question was "if I believe that the brace can change the image that my school friends have for me". We have divided in two groups 219 girls and 72 boys. The average age was 14, $5 y$ and the Cobb angle was from 19 to 64 and the Surface Rotation angle from $7^{\circ}$ to $24^{\circ}$. All the data were analyzed by statistical methods and the scores have been compared between the two groups.

\section{Results}

It was a net difference between the answers of the group of girls in confront of the second group in almost all the questions. There was an identical answer for three questions. The first was" it is hard for me to be open with my brace". The second was "I don't feel embarrassed to show my brace to people close to me (parents, friends and school friends)" and the third was our new added question "if I believe that the brace can change the image that my school friends have for me"

\section{Conclusion}

It seems that the adolescents girls have less compliance with the brace in general but all the adolescents in total they do not fear the opinion of the population in general as much as the opinion of the small competitive community of the school. We think that all the countries

Spondylos Laser Spine Lub, Athens, Greece

Full list of author information is available at the end of the article must stand on this problem and promote compliance through programs and information seminars at the schools.

Published: 10 September 2010

\section{doi:10.1186/1748-7161-5-S1-066}

Cite this article as: Papadopoulos: Investigation of the profound causes of the not brace compliance in adolescents. Scoliosis 2010 5(Suppl 1): O66.
Submit your next manuscript to BioMed Central and take full advantage of:

- Convenient online submission

- Thorough peer review

- No space constraints or color figure charges

- Immediate publication on acceptance

- Inclusion in PubMed, CAS, Scopus and Google Scholar

- Research which is freely available for redistribution

Submit your manuscript at www.biomedcentral.com/submit
C Biomed Central 